\title{
Induction of apoptosis by the aqueous and ethanolic leaf extract of Vitex negundo $L$. in MCF-7 human breast cancer cells
}

\author{
Arulvasu C.1*, Prabhu D.1, Manikandan R.2*, Srinivasan P.3, Dinesh D.1, Babu G.1 \\ Sellamuthu S.1 \\ 1'Department of Zoology, University of Madras, Chennai, 600025, Tamil Nadu, India, carulvasu@gmail.com \\ ${ }^{2}$ Department of Animal Health and Management, ${ }^{3}$ Department of Bioinformatics, Alagappa University, Karaikudi, 630003 , \\ Tamil Nadu, India
}

\begin{abstract}
The aim of this investigation was to evaluate the anti-proliferative potential of aqueous and ethanolic extract from Vitex negundo against human breast cancer cell (MCF-7). The aqueous and ethanol extract from $V$. negundo potently inhibited growth of MCF-7 in a concentration-dependent manner. $V$. negundo pretreatment resulted in deferential cell viability and IC50 value were observed in MCF-7 cell line but not in control cell line. The above result suggested that $V$. negundo has a potential benefits in breast cancer cells.
\end{abstract}

Keywords- Anti-cancer, anti-proliferative, breast cancer, cytotoxicity, V. negundo, MCF-7

\section{Introduction}

Cancer is the second leading cause of death worldwide and it is expected that around $26.6 \%$ of increase in the total number of cancer cases registered in India for the year 2008 [1] while in past years, cancer has been regarded mainly as a group of diseases afflicting the developed countries. Among the incidence of various forms of cancer is now rapidly rising worldwide, the breast cancer continues to be the most commonly diagnosed cancer [2]. The conventional treatment such as surgical resection, radiation therapy, and chemotherapy are not still satisfactory, prevention of this disease or at least stopping it at its inception is important. Because increasing evidence indicates that some plant components can suppress tumor development [3-5], identifying such factory may be an effective, non-invasive strategy for decreasing the incidence and severity of cancer. Medical plants have been used in Asian countries and interest in this area of research has recently increased in all over countries. Vitex negundo $L$. has been one of most widely used and welldocumented medicinal plants for centuries [6]. As a traditional medicine, a number of pharmacological activities have been attributed to $V$. negundo, such as analgesic and antiinflammatory activity [7], enzymes inhibition [8], nitric oxide scavenging activity [9], snake venom neutralization activity [10], anti-feeding activity [11], anti-radical and anti-lipoperoxidative [12], CNS activity [13], hepatoprotective activity [14], antibacterial activity [15], anti-fungal [16], larvicidal activity [17], anti-androgenic effects [18] mosquito repellent activity [19] and anti-diabetic effect [20]. However, in this study, we explored the possibility that extract of $V$. negundo have possesses anti-proliferative effects. We examined whether or not the crud extracts of $V$. negundo inhibit MCF-7 breast cancer cell growth and if the aqueous and ethanolic extract induce apoptosis.

\section{Materials and methods 2.1. Chemicals}

All the chemicals used were of analytical grade and purchased from Sigma (St. Louis, MO, USA). Dulbecco's Modified Eagle Medium (DMEM) fetal bovine serum (FBS) was purchased from GIBCO. 3-(4, 5- Dimethyl thiazol-2yl)-2, 5dimethyltetrazolium bromide (MTT), propidium iodide were purchased form Sigma chemical company (St. Louis, MO. USA).

\subsection{Collection of medicinal plant materials} The medicinal plant used in this study was collected from Ambattur, Chennai, Tamil Nadu, The plant was examined and identified by a botanist from Centre for Advanced Studies (CAS) in Botany, University of Madras, Guindy campus, Chennai, Tamil Nadu, India.

\subsection{Preparation of extracts}

Excised $V$. negundo leaf was thoroughly washed with tap water followed by sterile distilled water twice, shade dried at room temperature and powdered by using mortal pestle. The powdered plant material was percolated with $500 \mathrm{ml}$ of ethanol and aqueous $(5 \%(\mathrm{w} / \mathrm{v})$, the plant leaf extract was evaporated to dryness under reduced pressure and were stored at $-20^{\circ} \mathrm{C}$ until used. To test the biological activity, the dried crude extracts were dissolved in dimethyl sulfoxide (DMSO) to concentration of

$100 \mathrm{mg} / \mathrm{ml}$ stock solution; this was later mixed with the culture media (DMEM) to achieve the desired concentration.

\subsection{Cell lines and cell cultures}

MCF-7 (human breast cancer cell line) was obtained from the National Centre for Cell Science (NCCS), Pune, India. Cells were cultured in DMEM (St. Louis, Mo, USA) supplemented with $10 \%(\mathrm{v} / \mathrm{v})$ FBS, penicillin 100 $\mu \mathrm{g} / \mathrm{ml}$, streptomycin $20 \mu \mathrm{g} / \mathrm{ml}$, kanamycin acid sulphate $20 \mu \mathrm{g} / \mathrm{ml}$ and $7.5 \%$ sodium bi- 
carbonate solution. The cells were maintained as monolayers in $25 \mathrm{~cm} 2$ plastic tissue culture flasks at $37^{\circ} \mathrm{C}$ in a humidified atmosphere containing $5 \% \mathrm{CO} 2$ in air. Exponentially growing cells were used in all the experiments.

\subsection{MTT assay}

The effect of $V$. negundo on cells was determined with MTT (3-(4, 5-dimethylthiazol-2-yl)-2-5diphenyltetrazolium bromide) assay [21]. Briefly, the cells were plated at a density of $1 \times 104$ cells/well in $200 \mu$ of culture medium containing $100,200,300,400$ and $500 \mu \mathrm{g} / \mathrm{ml}$ freeze-dried aqueous extract in 96-well microtiter plates. A stock solution of ethanolic extract was prepared in DMSO and diluted with the culture media to achieve final concentrations of 100, 200, 300, 400 and $500 \mu \mathrm{g} / \mathrm{ml}$. The concentration of DMSO remained within the maximum permissible concentration of $0.1 \%$ in both control and treated samples were ensured. Each concentration of $V$. negundo was repeated in 10 wells. After incubation for the desired period of time at $37^{\circ} \mathrm{C}$ in a humidified incubator, cell viability was assessed. MTT assay (50 $\mu \mathrm{l}, 5 \mathrm{mg} / \mathrm{ml}$ in phosphate - buffered saline stock, diluted to a working strength of $1 \mathrm{mg} / \mathrm{ml}$ with media) was added to each well and incubated for $2 \mathrm{hr}$, after which the plate was centrifuged at $600 \mathrm{~g}$ for 5 $\min$ at $4^{\circ} \mathrm{C}$. The MTT solution was removed from the wells by aspiration. After removal of the medium, $0.1 \mathrm{ml}$ of buffered DMSO was added to each well and plates were shaken. The absorbance was measured at $570 \mathrm{~nm}$ in an automated plate reader and percentage of growth inhibition was calculated using the following standard.

Inhibitory rate $\%=$ Absorption control - Absorption test $\times 100$

$$
\text { Absorption test }
$$

\subsection{Nuclear morphological examination}

MCF-7cells were plated at $5 \times 104$ cells/well into a six-well chamber plate. At $>80 \%$ confluence, the cells were treated with leaf extract of $V$. negundo for $48 \mathrm{hr}$. The cells were washed with PBS fixed in methanol: acetic acid $(3: 1 \mathrm{v} / \mathrm{v})$ for $10 \mathrm{~min}$ and stained with $50 \mu \mathrm{g} / \mathrm{ml}$ of propidium iodide for 20 min. Nuclear morphology of apoptotic cells with condensed/fragmented nuclei was examined under a fluorescent microscope (Carl Zeiss Axiolab inverted Microscope) and at least $1 \times 103$ cells were counted to assess apoptotic cell death [22].

\subsection{DNA Fragmentation Assay}

DNA preparation an agarose gel electrophoresis was carried out according to a method previously reported [23]. Cells were cultured in $100 \mathrm{~mm}$ dishes treated with extract as described above and extracted for $2 \mathrm{hr}$ in an extraction buffer (50 $\mathrm{mM}$ of Tris, $\mathrm{pH} 7.5,20 \mathrm{mM}$ of EDTA and $1 \%$
Nonidet P-40). Sodium dodecyl sulfate was then added to $1 \%$ and the mixture was incubated with $500 \mu \mathrm{g} / \mathrm{ml}$ of proteinase $\mathrm{K}$ for $2 \mathrm{hr}$ at $42^{\circ} \mathrm{C}$. The mixture was then extracted with phenol: chloroform: isoamyl alcohol (25:24:1) and 2.5 volume of absolute ethanol. Equal amounts of DNA samples were electrophoresed on a $1.5 \%$ agarose gel in Tris-borate EDTA buffer and visualized by ethidium bromide staining under UV transilluminator.

\subsection{Statistical analysis}

All experiments were repeated three times and then data were shown as means \pm standard deviation (S.D) of three assays. Student t- test was applied, and $\mathrm{p}<0.05$ was considered as statistically significant.

\section{Results}

Aqueous and ethanolic extract of $V$. negundo leaves, resembled a dark brown colored paste and powdered which was found to be highly soluble in water, chloroform and ethanol. The plants may be considered as a biosynthetic laboratory, not only for primary chemical compounds such as carbohydrates, proteins and lipids that are utilized as food, but also for a multitude compounds like glycosides, tannins, alkaloids, volatile oils etc., that exert a physiological effect. The compounds that are responsible for therapeutic effect are usually secondary metabolites. The systemic study of the crude drug embrace through consideration of primary and secondary metabolites derived as a result of plant metabolism. Active metabolites of plants contribute for the widely varying physiological functions inhibited by them. In order to understand the effect of aqueous and ethanolic extract of $V$. negundo on breast cancer cell, experiments were conducted using cultured human breast carcinoma cells. Results of the viability test were measured using MTT spectophotometric assay. This method is based on the quantification of purple-colored formazan, which was formed by the reduction of MTT [3-(4, 5-dimethylthiazole-2-yl)-2,5-diphenyl

tetrazoliumbromide]. The reduction of MTT is proportional to the number of active mitochondria in the live cells. Dose-dependent inhibition of MCF-7 cells was observed at different concentrations $(100-500 \mu \mathrm{g} / \mathrm{ml})$ of aqueous and ethanolic extract of $V$. negundo treatment. At 200 and $300 \mu \mathrm{g} / \mathrm{ml}$, inhibition of MCF-7 cells was found to be $50.45 \%$ aqueous (viability) and $50.61 \%$ ethanolic extract (viability) respectively, at $24 \mathrm{hr}$ "Fig (1 A)". Further, the maximal cytotoxic activity at a concentration of aqueous and ethanolic extract of $V$. negundo treatment, at $500 \mu \mathrm{g} / \mathrm{ml}$, inhibition of MCF-7 cell was found to be $36.44 \%$ aqueous (viability) and $39.04 \%$ ethanolic (viability) respectively, at $48 \mathrm{hr}$ "Fig (1 B)". The morphological observation of MCF-7 
human breast cancer cells were stained with propidium iodide and morphological examination were observed under the fluorescence microscope. The aqueous extracts treatments were significantly observed the partial apoptosis occurs at the concentration of $300 \mu \mathrm{g} / \mathrm{ml}$ at $48 \mathrm{hr}$ when compared with control "Fig. (2 D)". But in ethanolic extract, the partial apoptosis was observed at the concentration of $200 \mu \mathrm{g} / \mathrm{ml}$ at 48 hr of incubation compared to control "Fig. (2 B)". Maximum apoptosis was observed in cells incubated with higher concentration $(500 \mu \mathrm{g} / \mathrm{ml})$ of both aqueous and ethanolic leaf extract "Fig. (2 C \& E)". It may be due to the growth inhibitory effect of aqueous and ethanolic extract of $V$. negundo. To determine whether or not the extract induces apoptosis of MCF-7 cells, we performed a DNA fragmentation assay. DNA isolated from cells treated with $200 \mu \mathrm{g} / \mathrm{ml}$ and $300 \mu \mathrm{g} / \mathrm{ml}$ of extract pattern that is characterize the apoptotic cell death after $48 \mathrm{hr}$ "Fig. (3 B \& C)". Maximal apoptosis was recorded after $48 \mathrm{hr}$ exposure of MCF-7 cells to $500 \mu \mathrm{g} / \mathrm{ml}$ of both aqueous and ethanolic leaf extract. These results suggest that $V$. negundo was induced and augmented the apoptosis in cancer cell line MCF-7 treated with both aqueous and ethanolic leaf extract "Fig . (3 $E$ \& F)".

\section{Discussion}

The rationale for selection of $V$. negundo for evaluation of its anti-cancer activity is that it has been used widely for many years as a traditional folk medicine and it has been shown to exert effects on various human illnesses. To date, several bioactive compounds from various medicinal plants have been identified that show anti-oxidant, anti-inflammatory and in some instances anti-cancer effects [24]. In our study, the aqueous and ethanolic extracts of $V$. negundo, rich in plant constituents may cause cell growth inhibition and induce apoptosis differentially in cancer cells. Apoptosis is a wellidentified biological response exhibited by cells after suffering DNA damage and is a useful marker for screening compounds for subsequent development as possible anticancer agents [25]. In this study, MCF-7 human breast cancer cells were treated with aqueous and ethanolic extract of $V$. negundo. The cell growth inhibitory effects of this plant crude extract support to exert their anti-cancer effects in vitro. Similarly, these results are consistent with previous studies [26, 27] and previously reported studies indicated that glycosidic compounds are possessing potent anti-carcinogenic properties in vivo [28, 29]. These compounds are able to inhibit cancer initiation, possibly through the induction of hepatic detoxifying enzymes as well as through their anti-oxidant properties. Flavonone glycons have anti-proliferative activities against many human cell lines like OCM-1, MCF-7 and HT-29
[30]. In our present investigations have demonstrated the $V$. negundo crude extract possesses significant anti-cancer properties and causes selective growth inhibition and apoptosis in cancer cells. We observed the maximum growth inhibitory effects (49.39\%) on MCF-7 human breast cancer cells at $300 \square \mathrm{g} / \mathrm{ml}$ of aqueous extract and $200 \square \mathrm{g} / \mathrm{ml}$ in the case of ethanol extract. In our experiments, we cannot attribute the differences in biological effects observed between the ethanolic and aqueous $V$. negundo extract. In the present investigation, the anti-cancer activity of $V$. negundo extract as a whole. Our data suggests that these extracts may show the greater effects than the individual constituents present in plant extracts. On the basis of the findings of this study, we are currently undertaking extensive experiments to characterize and identify bioactive compounds from $V$. negundo and their anti-cancer effects on cancer cell, MCF-7 human breast cancer cells in vitro. An important investigation leads to the possibility that synergistic combination of biologically active agents may exist naturally in plants, and to investigate whether such combinations may be clinically useful for anticancer and apoptotic agents.

\section{Acknowledgements}

The authors acknowledge the National Centre for Cell Science (NCCS), Pune for providing cancer cell lines.

References

[1] Marimuthu P. (2008) Ind. J. Cancer., 45, 47.

[2] Ganz P.A (2005) Amer. J. Med., 118, 136141.

[3] Khan M.T., Lampronti I., Martello D., Biarichi N. and Choundhuri M.S. (2002) Int. J. Oncol. 21, 182-192.

[4] Watanabe M., Hayakama S., Isemura M., Kumazawa, S. and Nakayama T. (2002) Biol. Pharm. Bull., 25, 1388-1390.

[5] Kim S.M., Lee J., Lee K.M., Yan S.H., Cho S. and Chung S.Y. (2003) Life Sci., 73, 1231-1243

[6] Tendon V.R. (2005) Nat. Prod. Rad., 4, 162-165.

[7] Dharmasiri M.G., Jayakody J.R., Galhena G., Liyanage S.S. and Ratnasooriya W.D. (2003) Journal Ethnopharmacology, 87, 199-206.

[8] Azhar-UI-Haq Malik A., Khan M.T., AnwarUl-Haq Khan S.B., Ahmad A. and Choudhary M.I. (2006) Phytomedicine, $13,255-260$.

[9] Jagetia G.C. and Baliga M.S. (2004) J. Med. Food., 7, 343-348.

[10] Alam M.I. and Gomes A. (2003) Journal of Ethnopharmacology, 86, 75-80. 
[11] Chandramu C., Manohar R.D., Krupadanam D.G. and Dashavantha R.V. (2003) Phytother. Res., 17, 129-134.

[12] Munasinghe T.C., Seneviratne C.K., Thabrew M.I. and Abeysekera A.M. (2001) Phytother. Res., 15, 519-523.

[13] Gupta M., Mazumder U.K. and Bhawal S.R. (1999) Indian J. Exp. Biol., 37, 143-146.

[14] Avadhoot Y. and Rana A.C. (1991) Arch. Pharm. Res., 14, 96-98.

[15] Perumalswamy R., Ignacimuthu S. and Sen A. (1998) Journal of Ethnopharmacology, 62, 173-182.

[16] Damayanti M., Susheela K. and Sharma, G.J. (1996) Cytobios., 86, 155-165.

[17] Pushpalatha E. and Muthukrishnan J. (1995) Ind. J. Malariol., 32, 14-23.

[18] Bhargava S.K. (1989) Journal of Ethnopharmacology, 27, 327-339.

[19] Hebbalkar D.S., Hebbalkar G.D., Sharma R.N., Joshi V.S. and Bhat V.S. (1992) Indian. J. Med. Res., 95, 200-203.

[20] Manikandan R., Sundaram R., Srinivasan P., Beulaja S. and Arulvasu C. (2009) Int. J. Pharmaceu. Analy., 1(2), 4-10

[21] Mosmann T. (1983) J. Immunol. Methods., 16, 55-63.

[22] Keum Y.S., Kim J. and Lee K.H. (2002) Cancer Letters, 177, 41-47.

[23] Kim E.J., Lee Y.J. and Shin H.K. (2005) Nutrition, 21, 1141-1148.

[24] Ogasawara M., Matsunaga T. and Suzuki K. (2007) Biol. Pharm. Bull., 30, 200204.

[25] Srivastava J. K. and Gupta S. (2007) J. Agric. Food Chem., 55, 9470-9478.

[26] Kawaii S., Yomono Y., Katase E., Ogawa K. and Yano M. (1999) Biosci. Biotechno. Biochem., 63, 896-899.

[27] Arulvasu C., Dinesh D., Manikandan R., Pandi M., Srinivasan P., Radakrishnan N., Sellamuthu S., Prabhu D. and Babu G. (2010) Int. J. Pharma. Tech. Resea., (In press)

[28] Tanaka T., Makita H., Kawabata K., Mori H., Kakumoto M., Satoh K., Hara A., Sumida T., Tanaka T. and Ogawa $H$. (1997) Carcinogenesis, 18(5),957-965.

[29] Yang M., Tanaka T., Hirose Y., Deguchi T., Mori H. and Kawada Y. (1997) Int. J. Cancer., 73, 719-724.

[30] Manthey J.A. and Guthrie N. (2002) J. Agric. Food Chem., 50,5837-5843. 


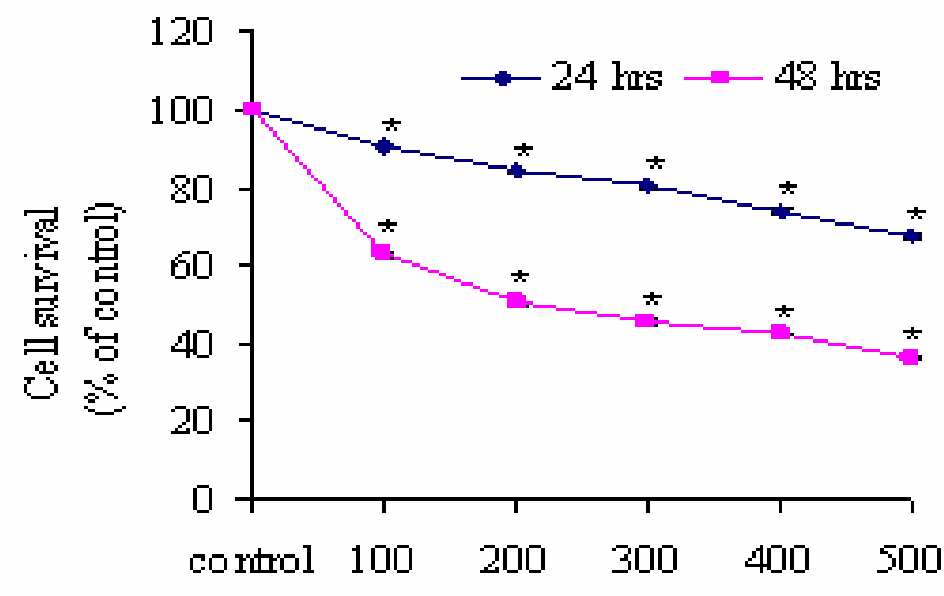

Different conce ntration of etharolis leaf extract

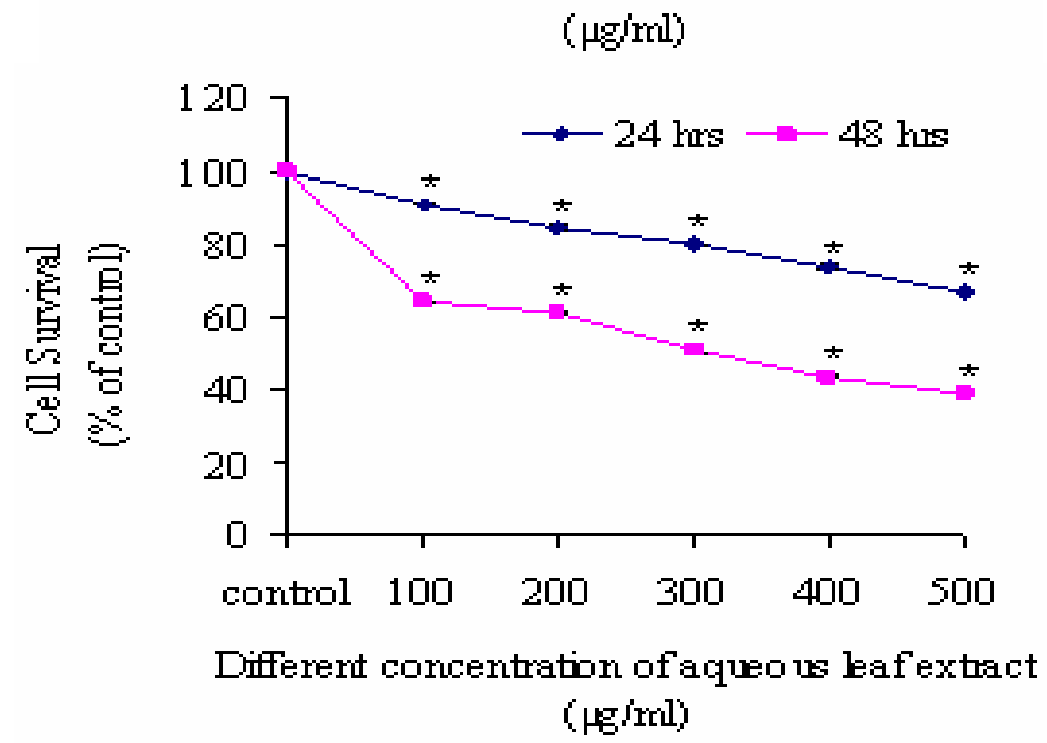

Fig. 1- Effect of $V$. negundo at different concentration of aqueous and ethanolic extract on the growth of MCF-7 cells. A- Ethanolic; B- Aqueous. Cell survival was measured using MTT assay and expressed as percentage of viable cells of treated samples to untreated control samples. Data are represented by mean \pm $\mathrm{SD}$ of three independent experiments each performed in tetrads. 

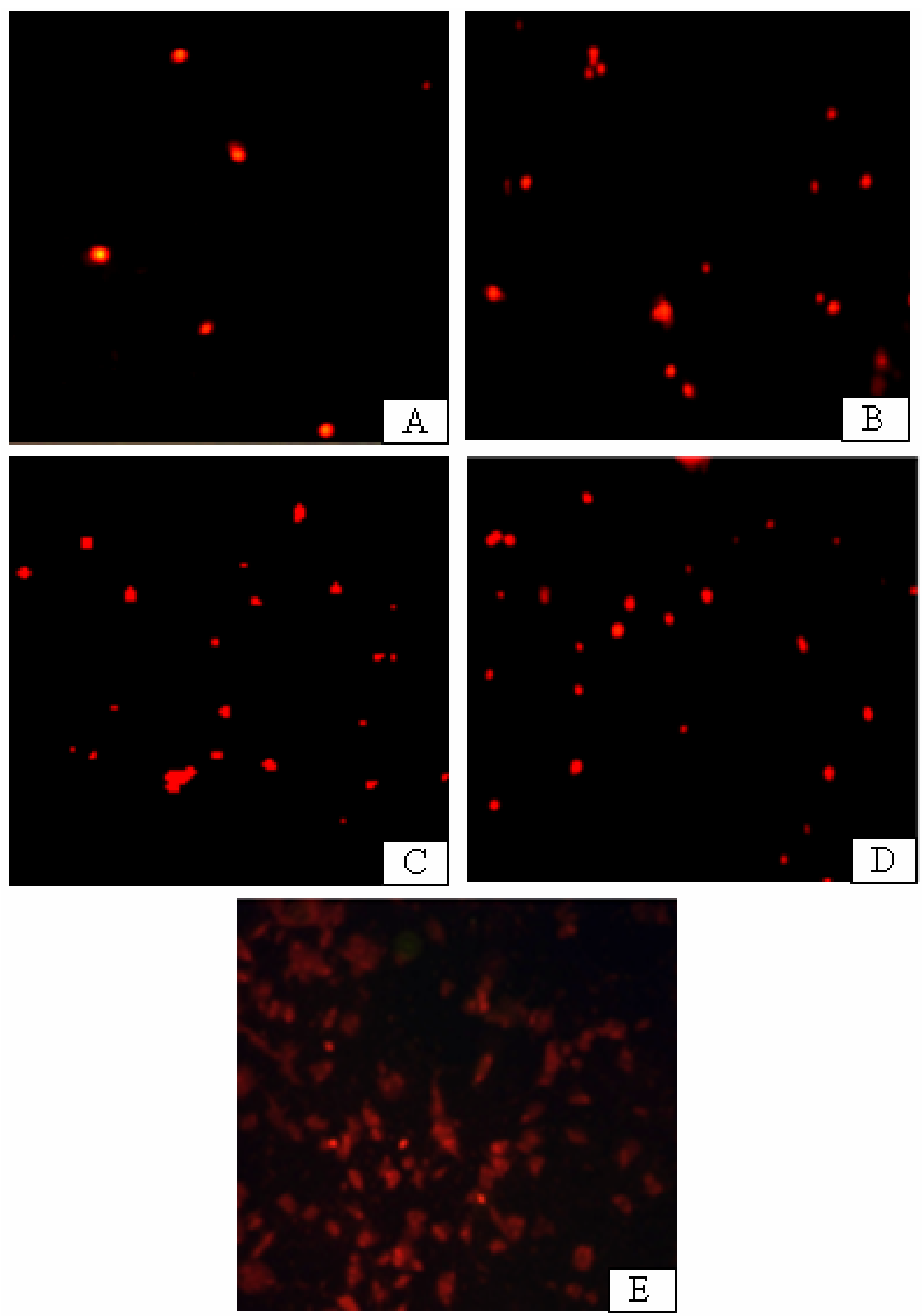

Fig. 2-Morphological changes and the number of apoptotic nuclei in MCF-7 after treatment with $V$. negundo for $48 \mathrm{hr}$. A-Control; B-200 and C-500 $\mu \mathrm{g} / \mathrm{ml}$ of ethanolic leaf extract and D- 300; E - $500 \mu \mathrm{g} / \mathrm{ml}$ of aqueous leaf extract after $48 \mathrm{hr}$ of incubation respectively. 
A

$\mathrm{B}$

C

$\mathrm{D}$

$\mathrm{E}$

$\mathrm{F}$

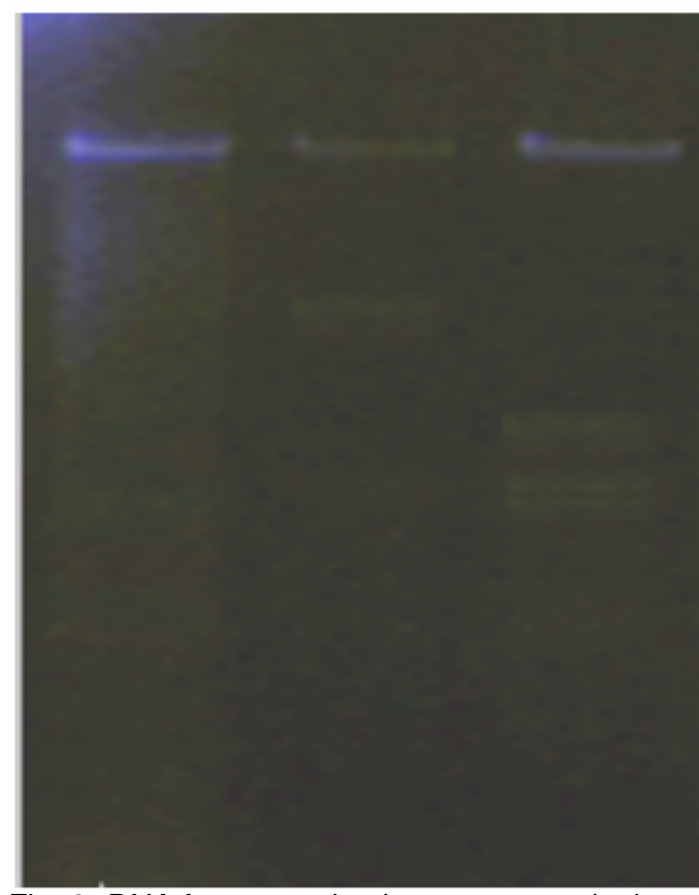

Fig. 3- DNA fragmentation in aqueous and ethonalic extract of $V$. negundo treated with MCF-7 cells. A \& DControl; B \& C- V. negundo at $200 \& 500 \mu \mathrm{g} / \mathrm{ml}$ ethanolic leaf extract and E \& F - V. negundo at $300 \& 500$ $\mu \mathrm{g} / \mathrm{ml}$ aqueous leaf extract for $48 \mathrm{hr}$ of incubation respectively. 